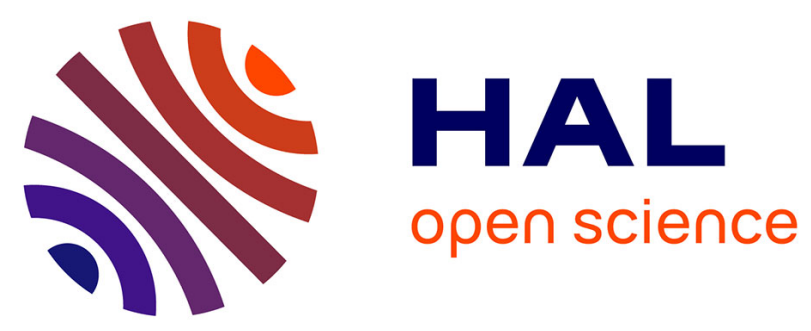

\title{
The Mt Cimone, Italy, free tropospheric campaign: principal characteristics of the gaseous and aerosol composition from European pollution, Mediterranean influences and during African dust events
}

Yves Balkanski, S. E. Bauer, R. van Dingenen, P. Bonasoni, M Schulz, H.

Fischer, G. P. Gobbi, M. Hanke, D. Hauglustaine, J. P. Putaud, et al.

\section{To cite this version:}

Yves Balkanski, S. E. Bauer, R. van Dingenen, P. Bonasoni, M Schulz, et al.. The Mt Cimone, Italy, free tropospheric campaign: principal characteristics of the gaseous and aerosol composition from European pollution, Mediterranean influences and during African dust events. 2003. hal-00327820

\author{
HAL Id: hal-00327820 \\ https://hal.science/hal-00327820 \\ Preprint submitted on 27 Mar 2003
}

HAL is a multi-disciplinary open access archive for the deposit and dissemination of scientific research documents, whether they are published or not. The documents may come from teaching and research institutions in France or abroad, or from public or private research centers.
L'archive ouverte pluridisciplinaire HAL, est destinée au dépôt et à la diffusion de documents scientifiques de niveau recherche, publiés ou non, émanant des établissements d'enseignement et de recherche français ou étrangers, des laboratoires publics ou privés. 


\section{The Mt Cimone, Italy, free tropospheric} campaign: principal characteristics of the gaseous and aerosol composition from European pollution, Mediterranean influences and during African dust events

Y. Balkanski ${ }^{1}$, S. E. Bauer ${ }^{1}$, R. van Dingenen ${ }^{2}$, P. Bonasoni $^{3}$, M. Schulz $^{1}$, H. Fischer ${ }^{4}$, G. P. Gobbi ${ }^{5}$, M. Hanke ${ }^{6}$, D. Hauglustaine ${ }^{1}$, J. P. Putaud ${ }^{2}$, A. Stohl ${ }^{7}$, and F. Raes ${ }^{2}$

${ }^{1}$ Laboratoire des Sciences du Climat et de l'Environnement, 91190 Gif-sur-Yvette Cedex, France

${ }^{2}$ Joint Research Center, 21020 Ispra, Italy

${ }^{3}$ CNR ISAC, via Gobetti, 40129 Bologna, Italy

${ }^{4}$ Max Planck Institute for Chemistry, POB 3060, 55020 Mainz, Germany

${ }^{5} \mathrm{CNR}$, Via Fosso del Cavaliere, 00133 Rome, Italy

${ }^{6}$ Max Planck Institute for Nuclear Physics, POB 103980, 69029 Heidelberg, Germany

${ }^{7}$ Technical University of Munich, 85354 Freising-Weihenstephan, Germany

Received: 18 December 2002 - Accepted: 14 March 2003 - Published: 27 March 2003

Correspondence to: Y. Balkanski (balkansk@Isce.saclay.cea.fr)
The Mt Cimone, Italy, campaign: gaseous and aerosol composition

Y. Balkanski et al.

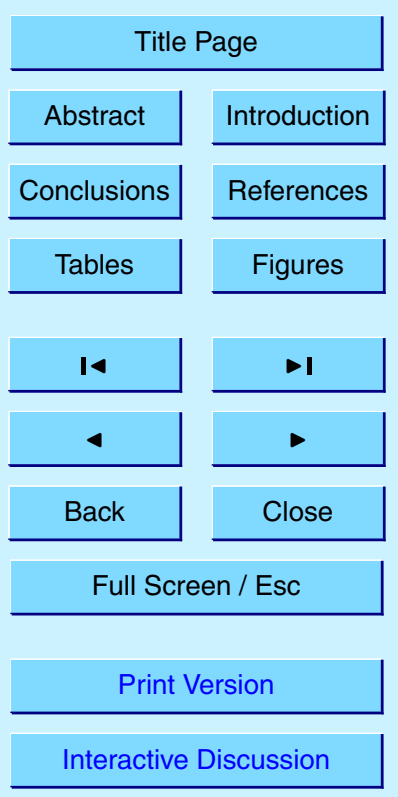

(C) EGU 2003 


\section{Abstract}

A 5 weeks experiment ( 1 June to 5 July 2000) took place at a mountain site, Mt Cimone $\left(44^{\circ} 11^{\prime} \mathrm{N}, 10^{\circ} 42^{\prime} \mathrm{E}, 2165 \mathrm{~m}\right.$ a.s.I. $)$, that is representative of Southern Europe background conditions. During this field campaign, a comprehensive characterisation

5 of trace gases and radicals, involved in the production and destruction of $\mathrm{O}_{3}$, as well as of chemical, physical and optical properties of the aerosol was done. Atmospheric gases and aerosols were measured continuously over the 5 weeks period, in order to characterize their background concentrations in the free troposphere and their respective differences in air containing dust aerosols advected from Africa. Due to its location

and elevation, Mt Cimone gets free tropospheric air both from the Mediterranean and from the Po Valley, which makes it an invaluable place to study gas/aerosol interactions.

A global chemical model coupled to a GCM was used to simulate based upon ECMWF reanalysis the ozone over the region during the period of the field study. The heterogeneous reactions of $\mathrm{O}_{3}, \mathrm{~N}_{2} \mathrm{O}_{5}, \mathrm{HNO}_{3}$ and $\mathrm{NO}_{3}$ were accounted for. We esti15 mate that during the field campaign, the effect of heterogeous reactions was to reduce by 8 to $10 \%$ the ozone concentration at MTC in cases when air had passed over the Mediterranean Sea. When air was coming from the Atlantic or continental Europe, the reduction of ozone is still $4 \%$. This reduction is mostly due to the large uptake of $\mathrm{HNO}_{3}$ and is the the topic of ongoing work to assess how it affects the global cycle of $\mathrm{O}_{3}$ and the global nitrogen budget.

\section{Introduction}

Dust provides surfaces for the gases to condense or be absorbed on. Numerous authors have reported observations of low ozone/high dust occurrences (Prospero et al., 1995; Dentener et al., 1996; Bonasoni et al., 1998; de Reus et al., 2000). Bonasoni et al. (1998) report concurrent measurements of dust and ozone at the Mt Cimone site over the March 1991 to December 1994 period. Dust reaching the site was identified
ACPD

3, 1753-1776, 2003

The Mt Cimone, Italy, campaign: gaseous and aerosol composition

Y. Balkanski et al.

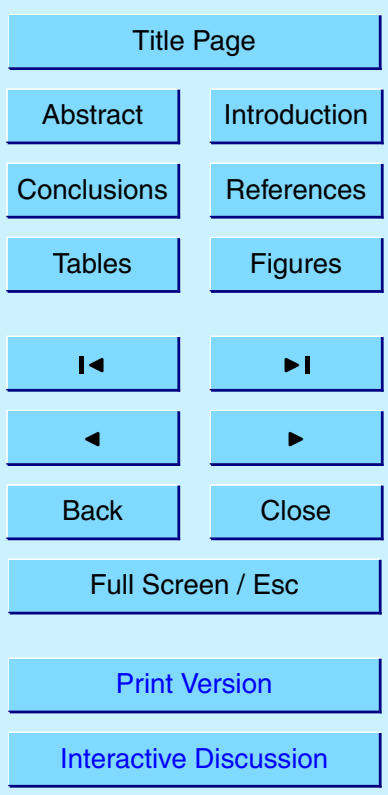

C) EGU 2003 
by the colorimetric Munsell soil-colour chart analysis. In 14 out of 20 events when dust reached the site in appreciable amounts, concurrent ozone measurements revealed ozone decreases when the dust-loaded air reached the site. In 3 of the remaining 6 cases, no significant $\mathrm{O}_{3}$ variation was detected, and in the other 3 cases ozone in5 creased. De Reus et al. (2000) analysed simultaneous airborne observations of dust aerosol and ozone acquired on 8 July over the North Atlantic as part of the ACE 2 experiment. The dust layer span from 2.5 to $5.5 \mathrm{~km}$ altitude and $\mathrm{O}_{3}$ concentrations were measured as consistently lower in the dust layer compared to the altitudes above $5.5 \mathrm{~km}$. The authors, using a box model which includes non methane hydrocarbon 10 chemistry, estimated a corresponding $\mathrm{O}_{3}$ loss of $4 \mathrm{ppbV}$ per day. Although a reaction involving metal ions has been proposed to be responsible for the loss in ozone, the chemical reactions responsible for a possible ozone reduction remain to be identified in the laboratory. Observational data of $\mathrm{NO}_{3}^{-}$and $\mathrm{nss}^{-\mathrm{Ca}^{2+}}$ indicate that high concentration of nitrate can be associated with calcium (Hirai et al. 1991; Prospero et al., 1995;

15 Fig. 2a in Dentener et al., 1996). During events of significant dust transport across the tropical Atlantic region, nitrate was found on the coarse mode of dust particles, suggesting its formation from nitrogen species on the dust particles (Prospero et al., 1995; Horai et al., 1993). In addition, Putaud et al. (this issue) show that nitrate is found on the coarse fraction of the aerosol and its formation is limited by ammonia availability. 20 Fewer studies have tried to quantify the proportion of dust grains actually coated by nitrate or sulfate. Parungo et al. (1995) used transmission electron microscopy and report that $40 \%$ of the particles captured over the China Sea region in the Asian outflow were covered by sulphate. Despite these reports, measurements are too limited to determine whether reactions involving $\mathrm{SO}_{2}, \mathrm{H}_{2} \mathrm{O}_{2}, \mathrm{~N}_{2} \mathrm{O}_{5}, \mathrm{HNO}_{3}$ and $\mathrm{O}_{3}$ are taking 25 place on the dust. This lack of observational evidence and of a mechanism to describe this gas/aerosol interactions motivated the pursuit of the MINATROC project, funded by the European Commission. Its goal is to document through laboratory, field and modelling work the heterogeneous processes occurring on dust. Two field campaigns are part of the project, of which the first one took place at Mt Cimone from 1 June to 5
ACPD

3, 1753-1776, 2003

The Mt Cimone, Italy, campaign: gaseous and aerosol composition

Y. Balkanski et al.

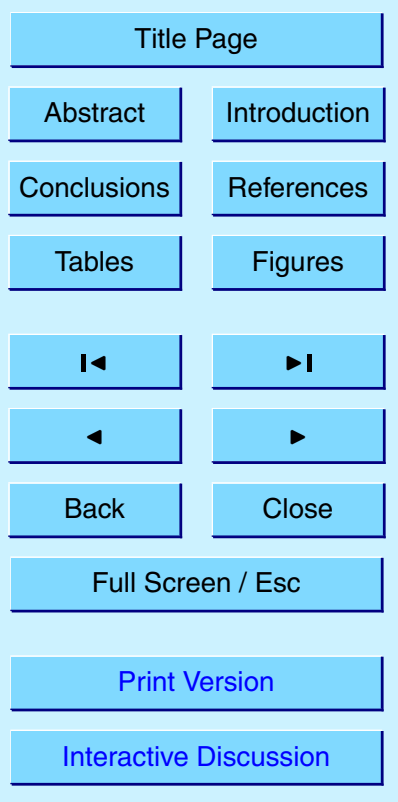

(C) EGU 2003 
July 2000. Its aim was to fully characterize the gas as well as the aerosol species with a complete set of measurements in order to identify heterogeneous reactions on dust. Additionally, optical characterisations of the aerosols encountered during the campaign were made. The campaign was set up to bring together simultaneous gas and aerosol 5 measurements in conditions when air devoid or laden with mineral dust reaches Southern Europe. These contrasted situations should allow for a quantification of the role of mineral dust in tropospheric chemistry.

Dry deposition of $\mathrm{O}_{3}$ on bare soil and sand suggests that uptake on dust is possible. Measurements of the accommodation coefficient of ozone on dust confirm this 10 (Hanisch and Crowley, 2002a). Further evidence gathered in laboratory studies shows that $\mathrm{HNO}_{3}$ uptake by dust surfaces is very efficient (Hanisch and Crowley, 2001a; Hanisch et al., 2001b). The uptake of $\mathrm{SO}_{2}$ on $\mathrm{CaCO}_{3}$ has also been measured using a low pressure Teflon coated reactor (Adams et al., 2002).

These studies raise the following questions: Why are $\mathrm{O}_{3}$ concentrations low in the 15 presence of dust? Is it due to air advected from $\mathrm{O}_{3}$-poor regions, or, are these low concentrations of $\mathrm{O}_{3}$ on dust due to heterogeneous reactions directly on the surface, to decreased photochemical production in the presence of dust clouds or limited $\mathrm{O}_{3}$ production due to low $\mathrm{NO}_{\mathrm{x}}$ availability? This paper attempts to answer the first question: are the ozone concentrations low due to advection from $\mathrm{O}_{3}$-poor regions before reaching Mt Cimone? A companion paper will address the role of heterogeneous reactions on ozone concentrations over the Mediterranean and Southern Europe.

In Sect. 1, we first review the measurements made in the course of the campaign. In Sect. 2, we distinguish the different influences at the site and propose a classification of the different air parcels encountered at the Mt Cimone station. The discussion in 25 Sect. 3 is based on ozone concentrations simulated either by accounting for homogeneous chemistry alone either with heterogeneous reactions included. Finally, the ozone concentrations are analysed from the point of view of the region over which the air parcel spent the most recent days of 5-day back trajectories.

\section{ACPD}

3, 1753-1776, 2003

The Mt Cimone, Italy, campaign: gaseous and aerosol composition

Y. Balkanski et al.

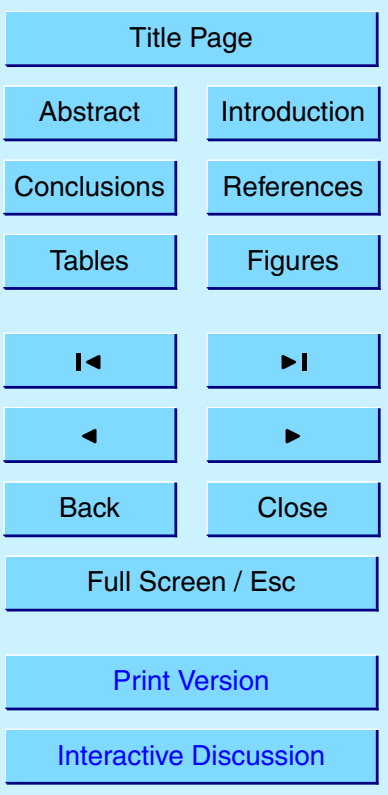

C) EGU 2003 


\section{Description of the gas, aerosol and meteorological measurements made at Mt Cimone, Italy}

Mt Cimone $\left(44^{\circ} 11^{\prime} \mathrm{N}, 10^{\circ} 42^{\prime} \mathrm{E}\right)$ is a Global Atmospheric Watch site (GAW), where background air pollution is monitored. The station is located on the highest peak of

5 the Northern Apennine chain at $2165 \mathrm{~m}$ a.s.l.. It is surrounded by a free horizon with the Mediterranean Basin on the South and Southwest side and overlooks the Po Valley on the North and Northeast side. Surface $\mathrm{O}_{3}, \mathrm{CO}_{2}$ and particulate matter are routinely monitored at the site, respectively since 1979 and 1991. In most conditions, air sampled at Mt Cimone is representative of free tropospheric air, but daytime summer measurements are affected by upslope winds, which occasionally deliver polluted air from the Po Valley to the site. During the campaign from 1 June to 5 July 2000, in-situ physical, chemical and radiative properties of the Mediterranean "free" troposphere were analyzed both during and without Saharan dust intrusions. The campaign at Monte Cimone (MTC), originally planned to last 4 weeks was extended by a $5^{\text {th }}$ week since no significant dust event had been observed during the first four weeks, but the meteorological forecast was favorable for the $5^{\text {th }}$ week. The elevation of the site ( $2165 \mathrm{~m}$ a.s.I.) provided an opportunity rarely taken before to study the remote troposphere over periods of several weeks. The diurnal variations of $\mathrm{NO}_{\mathrm{y}}, \mathrm{NO}_{\mathrm{x}}, \mathrm{O}_{3}, \mathrm{RO}_{\mathrm{x}}$, $\mathrm{CO}$, formaldehyde and VOCs unraveled that $\mathrm{O}_{3}$ was produced in this environment with little local pollution (see Fischer et al., 2002; Hanke et al., 2002). Table 1 indicates the instruments deployed and the measurements made during the campaign. The aerosol physical and chemical properties were identified through the following measurements (van Dingenen et al.; Putaud et al.; Gobbi et al., this issue):

- Number size distributions from Differential Mobility Analyzer (6-600 nm).

25 - Number distributions from Optical Particle Counter $(0.3-10 \mu \mathrm{m})$.

- Total number, surface area, volume concentration derived from DMA and OPC data.

The Mt Cimone, Italy, campaign: gaseous and aerosol composition

Y. Balkanski et al.

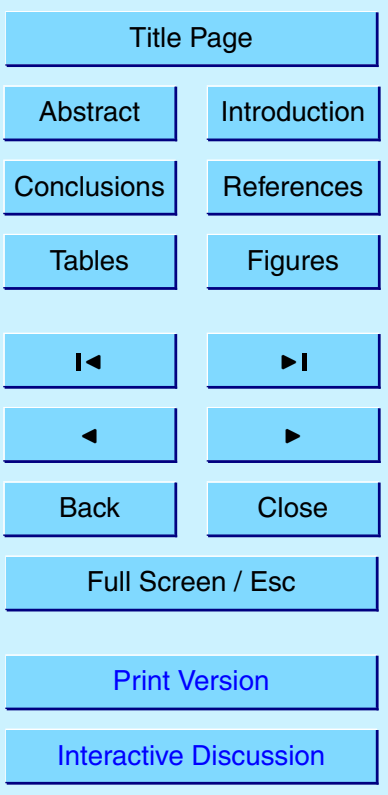

C) EGU 2003 
- High time resolution ionic composition in fine fraction $(<1 \mu \mathrm{m})$.

- Aerosol chemistry from impactor samples (of which OC/EC analysed at JRC).

3, 1753-1776, 2003

- Aerosol absorption coefficient and equivalent black carbon concentration.

- Aerosol hygroscopicity at $90 \% \mathrm{RH}$.

5 - Refractory aerosol size distributions.

The chemical composition of the aerosol was analysed by measuring on-line concentrations of the main ions $\left(\mathrm{Na}^{+}, \mathrm{NH}_{4}^{+}, \mathrm{K}^{+}, \mathrm{Mg}^{2+}, \mathrm{Ca}^{2+}, \mathrm{Cl}^{-}, \mathrm{NO}_{3}^{-}, \mathrm{SO}_{4}^{2-}\right)$ present in the submicron aerosol fraction. Sampling was done with $15 \mathrm{~min}$ time intervals using a wet aerosol denuder steam jet aerosol collector combination. The detection limits for o the setup is better than $0.1 \mu \mathrm{g} \mathrm{m}^{-3}$. For most of the campaign time, just $\mathrm{NH}_{4}^{+}, \mathrm{NO}_{3}^{-}$, and $\mathrm{SO}_{4}^{2-}$ were detected with significant concentrations (see Putaud et al., this issue). The displacement of $\mathrm{NO}_{3}^{-}$from the submicronic mode in the absence of dust, to the super micronic mode in the presence of dust is indicative of an efficient uptake of $\mathrm{HNO}_{3}$ on the dust surface. By opposition, Putaud et al., report could not detect any interaction 5 with $\mathrm{SO}_{2}$ during the dust episode.

\section{Identification of dust events and ozone concentrations during the campaign}

Gobbi et al. (this issue) report profiles of aerosol extintion, depolarisation, surface area and volume retrieved by the LIDAR during the MTC campaign. Furthermore, the authors attempted a closure analysis on the same quantities using aerosol size distri20 butions observed by the DMA and OPC instruments. During the 1-30 June period, no significant dust event was observed at the elevation of the site although the LIDAR evidenced 5 instances indicated in Fig. 1 when dust layers appeared aloft. Therefore, a large part of this data can be considered representative of continental background conditions. In only 1 case out of 5, from $2-4$ July 2000 , did the dust layers extend
The Mt Cimone, Italy, campaign: gaseous and aerosol composition

Y. Balkanski et al.

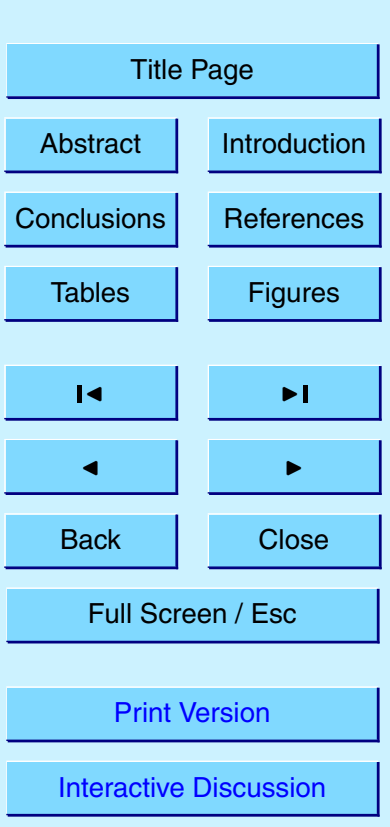

(C) EGU 2003 
down to the altitude of the Mt Cimone Observatory. This allowed for a full chemical characterization of the air mass. The arrival of the dust cloud at the site was clearly indicated by the OPC data where a significant increase in coarse aerosol number and volume was observed (Fig. 1). Although this last dust event was not particularly strong, 5 a maximum of 3.2 particles $/ \mathrm{cm}^{3}$ (size $>1 \mathrm{~mm}$ ) and a simultaneous $\mathrm{O}_{3}$ decrease was detected during the dust transport episode. A marked influence of Saharan dust on the $\mathrm{HNO}_{3}$ concentration could be registered (Hanke et al., 2002) during the dust intrusion of 3-4 July: at the onset of the dust event in the early morning of 3 July, the $\mathrm{HNO}_{3}$ concentration started to decrease continuously and reached its minimum in the early 10 morning of the next day. After a short period of passing clouds and slight rain around noon of 4 July, $\mathrm{HNO}_{3}$ recovered again. In contrast, $\mathrm{SO}_{2}$ does not show such a clear influence of dust. Both aerosol scattering and absorption coefficients are not significantly altered during the dust event. These parameters are dominated by the sub-micrometer aerosol (continental background) which is mixed with the dust.

15 3.1. The LMDZ-INCA model

LMDZ-INCA is composed of a chemical model (INCA: Interactions with Chemistry and Aerosols) which is embedded into a General Circulation Model (GCM) developed by the Laboratoire de Mtorologie Dynamique. INCA treats the emissions, photochemical transformations and deposition of chemical tracers interactively in the GCM. We used 20 a reasonably high resolution for a global model, $160 \times 98\left(2.25 \times 1.84^{\circ}\right.$ in respectively longitude and latitude) with $19 \sigma$-p hybrid vertical levels. The model is run in a nudged mode by relaxing the wind components to the corresponding ECMWF analysis. In this way the meteorological fields of the model are consistent with the actual meteorological conditions at the time of the sampling. The chemistry version used is based upon the 25 implementation of a methane oxidation scheme to calculate interactively tropospheric ozone and $\mathrm{OH}$. Emissions and chemistry of $\mathrm{CH}_{4}, \mathrm{CO}$, and $\mathrm{NO}_{x}$ are included. Typically this version includes 43 tracers and roughly 100 photochemical reactions and several aerosol types including dust are included with a spectral scheme to represent
ACPD

3, 1753-1776, 2003

The Mt Cimone, Italy, campaign: gaseous and aerosol composition

Y. Balkanski et al.

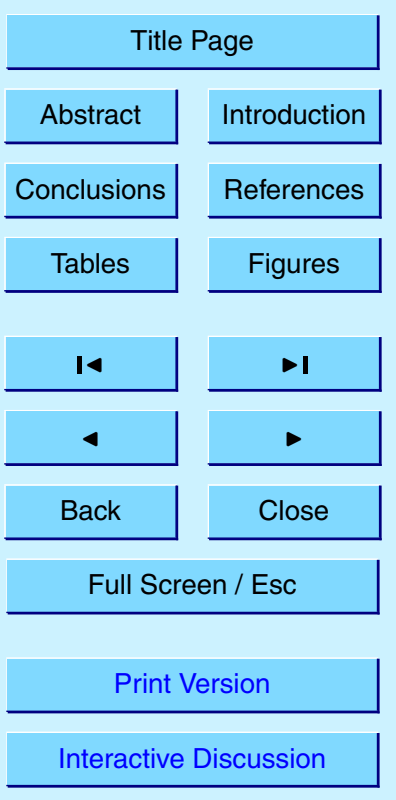

(C) EGU 2003 
size distribution. Different aerosol components are included in the model, in particular, seasalt, dust, sulfate and carbonaceous aerosols are explicitly resolved and we account for their solubility. The heterogeneous reactions of $\mathrm{O}_{3}, \mathrm{~N}_{2} \mathrm{O}_{5}, \mathrm{HNO}_{3}$ and $\mathrm{NO}_{3}$ on dust were included. The accomodation coefficient for these reactions were cho5 sen based upon laboratory studies that were performed within the MINATROC project (Hanisch and Crowley, 2001a; 2001b; 2002a and 2002b), respectively 1.e-5, 0.02 to 3.e-3 depending on relative humidity, 0.1 and 3.e-3. Note that the reaction of $\mathrm{NO}_{3}$ on dust has not been measured in the laboratory to our knowledge.

\subsection{Summertime ozone features simulated over the region}

10 The features of the ozone distribution are dominated in June by a maximum over Central Europe that extends to the Middle East region. Monthly mean ozone concentrations at the elevation of MTC $(780 \mathrm{mb})$ show a maximum over the region that covers the Middle East and parts of Central Europe (Fig. 2). The strong summertime $\mathrm{O}_{3}$ maximum over the Middle East region has been first documented by Li et al. (2001). Three sites, 15 Tel-Aviv, Dubai and Teheran, showed a pronounced maximum ozone concentration in the free troposphere. Simulated vertical profiles of ozone agreed well with measurements from the MOZAIC program aboard commercial aircraft (Marenco et al., 1998; Stohl et al., 2001). The maximum was attributed to a complex coupling between dynamical and chemical processes. During summer, ozone produced over the region experiences large scale subsidence which participates in the observed maximum. The position of this summertime maximum is best defined in the model at $400 \mathrm{mb}$ (upper panel of Fig. 2 and Fig. 1 of Li et al., 2001). Other contributions to this feature of the ozone distribution were identified by Li et al. (2001) by switching off the main sources of $\mathrm{O}_{3}$ precursors. Model results showed that sources from Europe and North Amer25 ica supply 4 to $12 \mathrm{ppbv}$ of $400 \mathrm{hPa} \mathrm{O}_{3}$ in the northern part of the Middle East region whereas Asian sources contribute to more than $8 \mathrm{ppbV}$ of ozone over its southern part. This ozone maximum is also simulated with the LMDZ-INCA model. In both months, June and July, $\mathrm{O}_{3}$ precursors produced over Western and Central Europe create rela-
ACPD

3, 1753-1776, 2003

The Mt Cimone, Italy, campaign: gaseous and aerosol composition

Y. Balkanski et al.

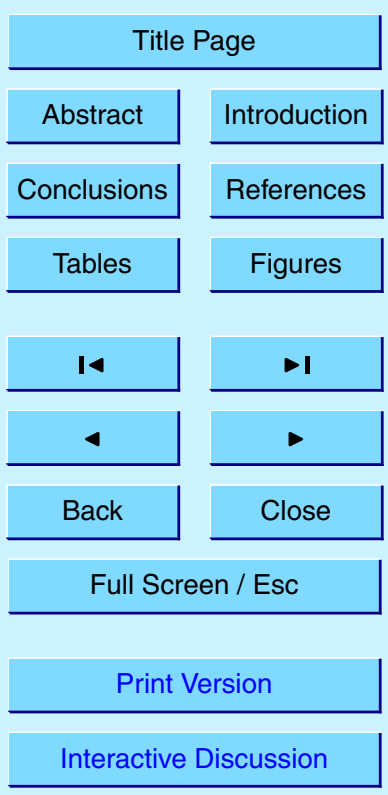

C) EGU 2003 
tively strong North-South and East-West gradients across the Mediterranean Sea (see Fig. 2, lower panel). Over the African continent, the East-West ozone concentration gradient reflects the circulation of air from the South of the ozone maximum located over the Middle East to the African region. In addition, ozone precursors from Europe 5 are transported over the Eastern Mediterranean region.

Air mass back trajectories arriving at the site were analysed to study whether changes in gas/aerosol concentrations and composition were attributable to the emissions over a wide geographical region. These trajectories were computed using the FLEXTRA model (Stohl et al., 1995). Following the study of Bonasoni et al. (2000) for Mt Cimone, 10 six regions were identified as having different signatures (see Fig. 3). These regions are: North-West Europe (NW-EUR), Atlantic-West Europe (ATL/W-EUR), Eastern Europe (E-EUR), the Mediterranean region (MED), Africa (AFR) and Arctic (ARC). Back trajectories were assigned to one of these regions based upon where the air parcel spent most of its time before its arrival at MTC (Fig. 3). Hence a trajectory is chosen

to be from a given sector based upon air mass characteristics of the region during its transit to the receptor site, as in the study of Pochanart et al. (2001) who showed that gases and aerosol properties strongly depend on the number of days a parcel spends over a given source region.

\section{Discussion of the ozone concentrations at Mt Cimone}

20 The ozone field shown on Fig. 2 (bottom panel) for June indicates that the main gradients for ozone across the Mediterranean Region are a North-South and an East-West gradient. The ozone time series at MTC during the period 1 June-5 July 2000 is presented in Fig. 4 together with the concentrations simulated by the LMDZ-INCA model with the assumption of homogeneous chemistry alone (top panel) and the heteroge- neous reactions listed above included (bottom panel). The whole period can be divided into 5 phases where the station received different air mass influences:
ACPD

3, 1753-1776, 2003

The Mt Cimone, Italy, campaign: gaseous and aerosol composition

Y. Balkanski et al.

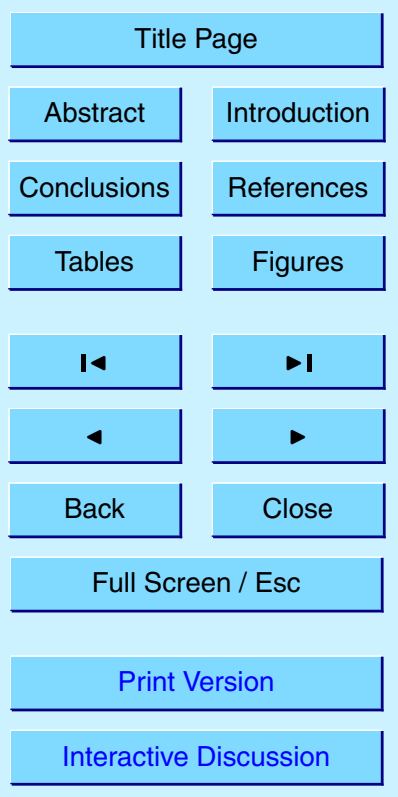

C) EGU 2003 
- 1-5 June is characterised by high ozone concentrations ( 62 to $75 \mathrm{ppbV}$ ) with back trajectories coming from W-EUR, NW-EUR and on 5 June from E-EUR.

- The next period spans 10 days from 6-15 June and is dominated by influences coming from the MED region with boundary layer air arriving at the site as indicated by the number of Aitken nuclei.

- A period of 3 days (16-18 June) follows, when air coming from NW-EUR and E-EUR brings about high ozone concentrations (64 to $68 \mathrm{ppbV}$ ). For all three periods presented so far, simulated ozone concentrations agree very well with the measured ones and the heterogeneous reactions are not important.

- The next and longest period spans from 19-30 June. Very low ozone concentrations occur in 2 instances: on 19 June and for 2 consecutive days, 25 and 26 June. On the first instance air coming from the Arctic brings about low ozone concentration, this situation is not reproduced by the model. On 25-26 June, the air is advected from the boundary layer over W-EUR with remarquably low concentrations (50-51 ppbV) which is captured by the simulation.

- Finally, the last period (1-5 July) which includes the dust episode recorded at Mt Cimone, is characterised by air masses coming from the Mediterranean and African regions. This is when the influence of the heterogeneous reactions is most clear. The model reproduces well both the decline and the recovery in ozone concentrations and overpredicts slightly the dip in daily mean concentrations that accompany the dust on 3 and 4 July (Fig. 4).

To find out whether the low ozone concentrations that are observed together with dust events are attributable to the photochemical regime over the regions of dust production rather than to heterogeneous processes on the surface of dust, we examined ozone concentrations along the computed back trajectories arriving at MTC. We used 5 days back trajectories that were computed every $3 \mathrm{~h}$. At each grid box location along the back trajectory, daily mean ozone concentrations simulated by LMDZ-INCA were

\section{The Mt Cimone, Italy, campaign: gaseous and aerosol composition}

Y. Balkanski et al.

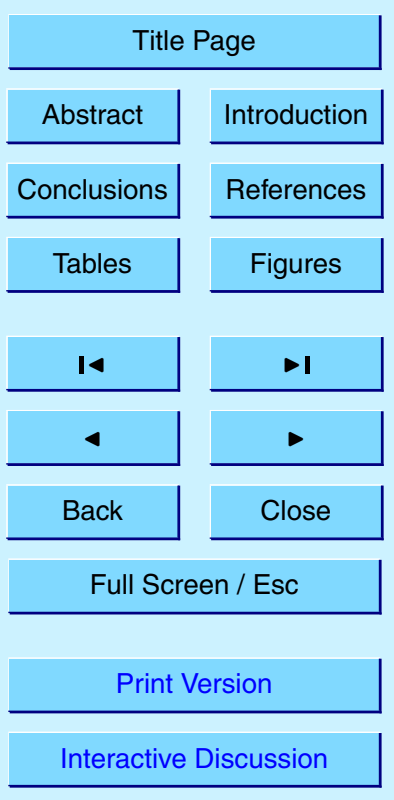

(C) EGU 2003 
recorded. Figure 5 presents the $\mathrm{O}_{3}$ concentrations at the time of arrival and for each of the 5 days preceding the arrival at MTC in the case ran with homogeneous chemistry. The influence of the origin of the air masses on ozone concentrations can be grouped into two categories. For air masses originating from NW-EUR, W-EUR and E5 EUR the averaged ozone concentration measured at MTC over the period is $60 \mathrm{ppbV}$ (resp. from 61 to $67 \mathrm{ppbV}$ in the model). In the 24-h before the arrival of the air mass at MTC the averaged simulated ozone concentrations only differ by 1 to $5 \mathrm{ppbV}$ (Table 2). The concentrations averaged over 24-h periods from day 2 to 5 of along the back trajectories are indicated in Table 2. Air masses originating either the MED and 10 AFR regions arrive at MTC with lower ozone concentrations than from any european sector. Measured averaged ozone concentrations are 57 and $56 \mathrm{ppbV}$, respectively for Mediterranean and Africa sectors. The simulated ozone concentrations for the same regions are 61 and $57 \mathrm{ppbV}$, respectively (Table 2). The comparison of the concentrations between the simulation with homogeneous reactions and heterogeneous reactions permits to quantify the effect of these reactions (Table 2). For air coming from the MED and AFR regions, the ozone concentrations at MTC, indicative of free tropospheric air, are reduced respectively by 5 and $6 \mathrm{ppbV}$ (respectively 8 and 10\%) due to heterogeneous chemistry. The uptkake of $\mathrm{HNO}_{3}$ onto mineral dust is important since a change in $\mathrm{NO}_{y}$ will influence both $\mathrm{O}_{3}$ and $\mathrm{NO}_{x}$ concentrations. The measurements of uptake coefficients of $\mathrm{HNO}_{3}$ on $\mathrm{CaCO}_{3}$ and mineral dust using a Knudsen reactor have lead to large differences: Underwood et al. (2001) reported a $\gamma$ of approximately $10^{-5}$, whereas Hanisch et al. (2001b) measured an accomodation coefficient of $10^{-1}$. Working with an aerosol flow reactor that allows to mimick better the flow of $\mathrm{HNO}_{3}$ than in the case of the Knudsen reactor, (Hanisch and Crowley, 2002) using genuine Saha25 ran dust found an accomodation of 0.1 equal to the one deduced from their Knudsen reactor experiments. This very fast uptake of $\mathrm{HNO}_{3}$ on dust is consistent with the very steep decrease in concentration that Hanke et al. report in this issue.

ACPD

3, 1753-1776, 2003

The Mt Cimone, Italy, campaign: gaseous and aerosol composition

Y. Balkanski et al.

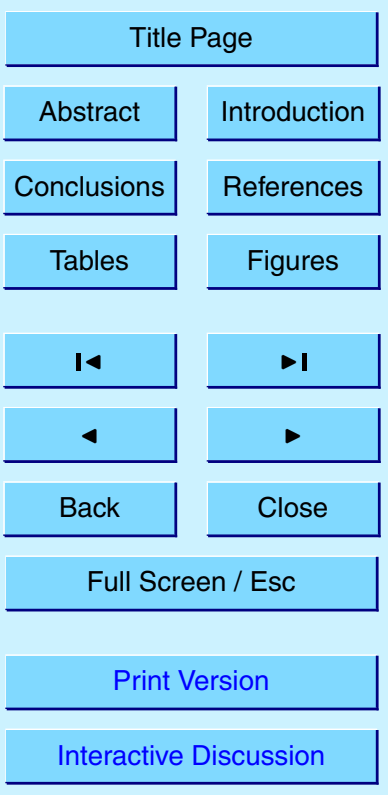




\section{Conclusions}

In conclusion, an unprecedented, high quality data set has been obtained for the period 1 June-5 July 2000, characteristic of both continental background conditions as well as a moderate dust episode. A comprehensive dataset on aerosol as well as gas phase 5 properties is available for process studies as well as for model validation.

A global chemical model coupled to a GCM was used to simulate based upon ECMWF reanalysis the ozone over the region during the period of the field study. The ozone concentrations over Southern Europe and the Mediterranean region are dominated over the summer by a maximum over Central Europe and the Middle East 10 region.

Daily mean ozone concentrations at Mt Cimone are $4 \mathrm{ppbV}$ lower when air is advected from the Mediterranean Basin or Africa rather than when air was advected from Europe.

The effect of heterogeneous chemistry estimated using accomodation coefficient reported by the latest laboratory studies is to reduce by 8 to $10 \%$ the ozone concentration at MTC in cases when air had passed over the Mediterranean Sea. When air was coming from the Atlantic or continental Europe, the reduction of ozone is still $4 \%$. This reduction which is partly due to the large uptake of $\mathrm{HNO}_{3}$, is the the topic of ongoing work to assess its effect on $\mathrm{O}_{3}$ and $\mathrm{NO}_{x}$ on the global scale.

Acknowledgements. This work was supported by the European Commission (DG XII) in the frame of the project EVK2-CT-1999-00003 MINATROC.

\section{References}

Adams, J. R. and Cox, P: Griffiths and D. Stewart, Reactive uptake of gases on mineral aerosols, in Proceedings of the $27^{\text {th }}$ General Assembly of the European Geophysical So-

\section{ACPD}

3, 1753-1776, 2003

The Mt Cimone, Italy, campaign: gaseous and aerosol composition

Y. Balkanski et al.

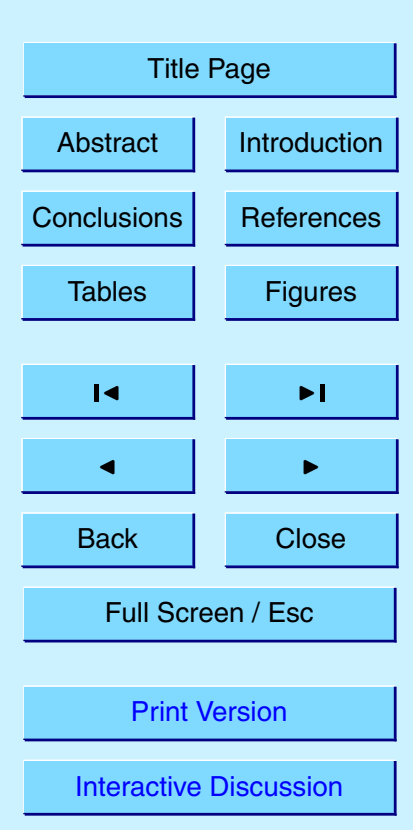

C) EGU 2003 
Bauer S., Balkanski, Y., Schulz, M., Hauglustaine D., and Dentener, F.: Heterogeneous chemistry on mineral dust aerosol surfaces: Influence on the global tropospheric ozone chemistry, to be submitted to J. Geophys. Res., 2003.

Bonasoni P., Bonafé, U., Colombo, T., Santaguida, R., Lenaz, R., and Tesi, G.: Effect of dust transport on trace gases concentration, in: XVIII Quade. Ozone Symp., l'Aquila, Italy, 12-21 September 1996, Bojkov, Visconti (Eds.), 323-326, 1998.

Bonasoni P., Stohl , A., Cristoganelli, P., Calzolari, F., and Colombo, T.: Bakground ozone vriations at Mt Cimone Station, Atmospheric Environment, 34, 5183-5189, 2000.

Bonasoni, P., Cristofanelli, P., Calzolari, F., Bonafé, U., Evangelisti, F., Van Dingenen, R., Colombo, T., and Balkanski, Y.: Aerosol and ozone correlation during the dust transport episodes of the summer-autumn 2000 period, this issue.

Dentener F. J., Carmichael, G. R., Zhang, Y., Lelieveld, J., and Crutzen, P. J.: Role of mineral dust as a reactive surface in the global troposphere, J. Geophys. Res., 101, 22 869-22 889, 1996.

de Reus, M., Dentener, F., Thomas, A., Borrmann, S., Ström, J., and Lelieveld, J.: Airborne observations of dust aerosol over the North Atlantic Ocean during ACE2: Indications for heterogeneous ozone destruction, J. Geohpys. Res., 105, D12, 15263-15275, 2000.

Fischer, H., Kormann, R., Klüpfel, T., Gurk, Ch., Königstedt, R., Parchatka, U., Mühle, J., Rhee, T. S., Brenninkmeijer, C. A. M., Bonasoni, P., and Stohl, A.: Ozone production and trace gas correlations during the June 2000 MINATROC intensive measurement campaign at Mt. Cimone, Atmos. Chem. Phys. Discuss., 2, 1509-1543, 2002.

Gobbi, G. P., Barnaba, F., Van Dingenen, R., Putaud, J. P., Mircea, M., and M. C. Facchini: Lidar and in situ observations of continental and saharan aerosol: closure analysis of particles optical and physical properties, this issue.

Gobbi, G. P., Barnaba, F., Giorgi R., and Santacasa, A.: Altitude-resolved properties of a Saharan dust event over the Mediterranean, Atmospheric Environment, 34, 5119-5127, 2000.

Hanisch, F. and Crowley, J. N.: Heterogeneous reactivity of gaseous nitric acid on $\mathrm{Al}_{2} \mathrm{O}_{3}$, $\mathrm{CaCO}_{3}$, and atmospheric dust samples: A Knudsen cell study, J. Phys. Chem., 105, 30963106, 2001a.

30 Hanisch, F. and Crowley, J. N.: The heterogeneous reactivity of gaseous nitric acid on authentic mineral dust samples, and on individual mineral and clay mineral components, Phys. Chem. Phys., 3, 2474-2482, 2001b.

Hanisch, F. and Crowley, J. N.: Ozone decomposition on Saharan dust: an experimental inves-

ACPD

3, 1753-1776, 2003

The Mt Cimone, Italy,

campaign: gaseous

and aerosol

composition

Y. Balkanski et al.

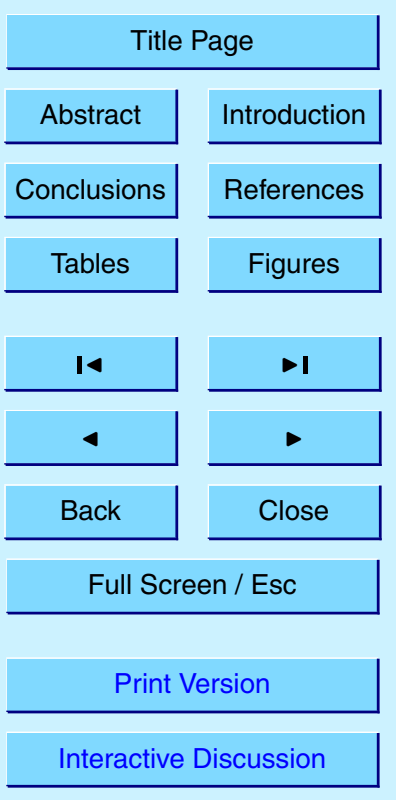

(C) EGU 2003 
tigation, Atmos. Chem. Phys. Discuss., 2, 1809-1845, 2002a.

Hanisch, F. and Crowley, J. N.: Heterogeneous reactivity of $\mathrm{NO}$ and $\mathrm{HNO}_{3}$ on mineral dust in the presence of ozone, submitted to Phys. Chem. Phys., 2002b.

Hanke M., Umann, B., Uecker, J., Arnold, F., and Bunz, H.: Atmospheric measurements of gas-phase $\mathrm{HNO}_{3}$ and $\mathrm{SO}_{2}$ using chemical ionization mass spectrometry during the minatroc field campaign 2000 on Monte Cimone, Atmos. Chem. Phys. Discuss., 2, 2209-2258, 2002.

Hirai E., Miyazaki, M., Chohji, T., Lee, M., Kitamura, M., and Yagamuchi, K.: Effect of Kosa aerosol on inorganic ion components in rainwater collected in cicum-pan-Japan-Sea area, Proceeding of the 2nd IUAOOA Regional conference on Air Pollution, Seoul, Korea, Korea

10 Air Research Association, 27-34, 1991.

Horai, S., Minari, I., and Migita, Y.: Aerosols Composition In Kagoshima in the Annual Report of the Kagoshima Prefectural Institute, 9, 1993.

Li, Q., Jacob, D. J., Logan, J. A., Bey, I., Yantosca, R. M., Liu, H., Martin, R. V., Fiore, A. M., Field, B. D., and Duncan, B. N.: A trospospheric maximum ozone over the Middle East,

15 Geophys. Res. Let., 28, 3235-3238, 2001.

Marenco, A., Thouret, V., Nédélec, P., et al.: Measurement of ozone and water vapor by Airbus in-servive aircraft: The MOZAIC airborne program, An overview, J. Geophys. Res., 103, 25631-25 642, 1998.

Parungo, F., Kim, Y., Zhu, C.-J., et al.: Asian dust storms and their effects on radiation and climate, STC Rep. 2906, (available from Science and Technology Coporation, 101 Research Drive, Hampon, VA. 23666, USA), 1995.

Pochanart, P., Akimoto, H., Maksyutov, S., and Staehelin, J.: Surface ozone at the Swiss Alpine site Arosa: the hemispheric background and the influence of large-scale anthropogenic emissions, Atmospheric Environment, 35, 5553-5566, 2001.

Prospero, J. M., Schmidtt, R., Cuevas, E., Savoie, D. L., Graustein, W. C., Turekian, K. K., VolzThomas, A., Dias, A., Oltmas, S. J., and Levy II, H.: Temporal variability of summer-time ozone and aerosols in the free troposphere over the eastern North Atlantic, Geoph. Res. Let., 22, 2925-2928, 1995.

Putaud J. P., van Dingenen, R., Dell'Acqua, A., Matta, E., Decesari, S., Facchini, M. C., and Fuzzi, S.: Size-segregated aerosol mass closure and chemical composition in Monte Cimone (I) during Minatroc, this issue.

Stohl, A., Wotawa, G., Seibert, P., and Kromp-Kolb, H.: Interpolation errors in wind fields as a function of spatial and temporal resolution and their impact on different types of kinematic

ACPD

3, 1753-1776, 2003

The Mt Cimone, Italy, campaign: gaseous and aerosol composition

Y. Balkanski et al.

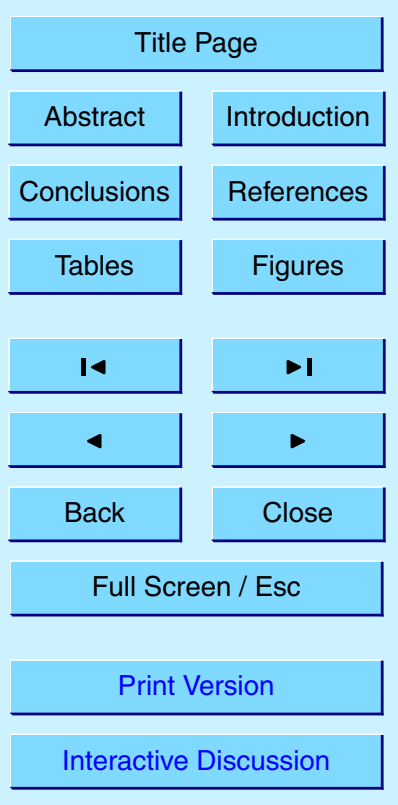

C) EGU 2003 
trajectories, J. Appl. Meteorology, 34, 2149-2165, 1995.

Stohl, A., James, P., Forster, C., Spichtinger, N., Marenco, A., Thouret, V., and Smit, H. G.

\section{ACPD} J.: An extension of Measurements of Ozone and Water Vapor by Airbus In-service Aircraft (MOZAIC) ozone climatologies using trajectory statistics, J. Geophys. Res., 106, $27757-$ $27768,2001$.

Underwood, G. M., Li, P., Al-Abadleh, H., and Grassian, V. H.: A Knudsen Cell Study of the Heterogeneous Reactivity of Nitric Acid on Oxide and Mineral Dust Particles, Journal of Physical Chemistry A, 105, 6609-6620, 2001.

Van Dingenen, R., Putaud, J.-P., and Raes, F.: Physical aerosol properties and their relation to air mass origin at Monte Cimone (Italy) during the first MINATROC campaign, this issue.

The Mt Cimone, Italy, campaign: gaseous and aerosol composition

Y. Balkanski et al.

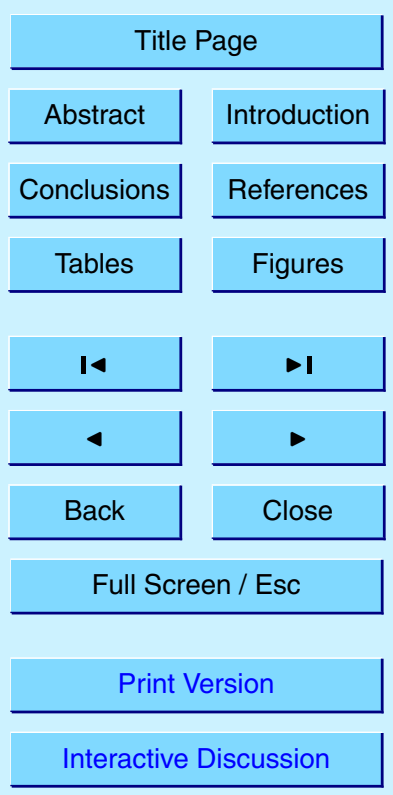




\section{ACPD}

Table 1. Overview of instrumentation and methods deployed during the Monte Cimone campaign (to be continued on next pages)

\begin{tabular}{lll}
\hline Parameter & Instrument/method & Partner \\
\hline \multicolumn{1}{c}{ Gas phase chemistry } \\
$\mathrm{HO}_{2}$ and $\sum \mathrm{RO}_{2}$ & ROXMAS & MPIK Heidelberg \\
$\mathrm{SO}_{2}$ and $\mathrm{HNO}_{3}$ & $\mathrm{CIMS}$ & MPIK Heidelberg \\
$\mathrm{SO}_{2}$ and $\mathrm{HNO}_{3}$ & Wet annular denuder + IC & $\mathrm{JRC}$ Ispra \\
$\mathrm{O}_{3}$ & UV absorption & CNR-ISAO, MPIK Heidelberg \\
$\mathrm{CO}_{2}$ & ULTRAMAT-5E Siemens NDIR & CNR-ISAO+AM CAMM \\
$\mathrm{NO}_{2}, \mathrm{HCHO}, \mathrm{H}_{2} \mathrm{O}_{2}^{(*)}$ & TDLAS & MPI Mainz \\
$\mathrm{NO}^{(*)}$ & Chemiluminescence detector (CLD) & MPI Mainz \\
$\mathrm{NO}_{\mathrm{y}}^{(*)}$ & Catalytic converter + CLD & MPI Mainz \\
$\mathrm{CO}^{(*)}$ & GC + FID & MPI Mainz, CNR-ISAO \\
$\mathrm{RO}_{x}$ & peroxy radical chemical amplifier & MPI Mainz \\
$\mathrm{NMVOC}^{(\#)}$ & Canister sampling + off-line analysis & MPI Mainz \\
$\mathrm{J}\left(\mathrm{O}^{1} \mathrm{D}\right)^{(*)}$ & up-and downward radiation flux in the UV-B range & MPI Mainz \\
\hline
\end{tabular}

${ }^{(*)}$ Not available during the dust event.

(\#) Ethane, ethene, propane, propene, iso-butane, butane, acetylene, trans-2-butene, 1-butene, iso-butene, cis-2-butene, 2-methylbutane, pentane, propine, 1,3-butadiene, trans-2-pentene, cis-2-pentene, cyclohexane, 2-methylpentane, 3-methylpentane, hexane, isoprene, heptane, benzene, toluene, sulfur hexafluoride, carbon dioxide, methane, nitrous oxide.
$3,1753-1776,2003$

The Mt Cimone, Italy,

campaign: gaseous and aerosol composition

Y. Balkanski et al.

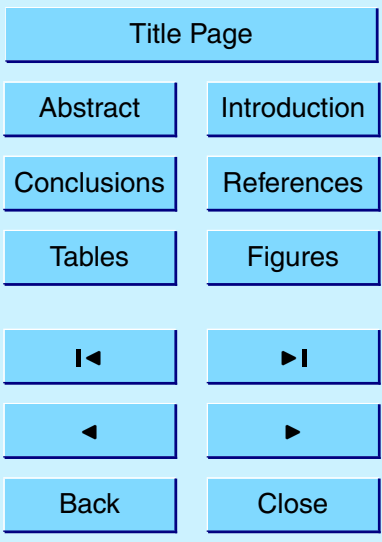

Full Screen / Esc

Print Version

Interactive Discussion 


\section{ACPD}

Table 1. Continued.

3, 1753-1776, 2003

\begin{tabular}{|c|c|c|}
\hline Parameter & Instrument/method & Partner \\
\hline \multicolumn{3}{|c|}{ Aerosol chemistry } \\
\hline $\begin{array}{l}\text { Water soluble inorganic }+ \text { water } \\
\text { soluble organic content }+E C+ \\
\text { gravimetric mass ( } 12 \mathrm{~h} \text { time resolution) }\end{array}$ & $\begin{array}{l}5 \text { stage impactor, double substrate. } \\
\text { Analysis with IC, Total Organic Carbon } \\
\text { analyzer, speciation of WSOC by HNMR }\end{array}$ & CNR-ISAO \\
\hline $\begin{array}{l}\text { Major ions } \\
\text { (15 min time resolution) }\end{array}$ & $\begin{array}{l}\text { Steam jet aerosol collector }+ \text { IC on-line } \\
\text { (fine/coarse fraction), artefact-free }\end{array}$ & JRC Ispra \\
\hline $\begin{array}{l}\text { Major ions } \\
\text { (12h time resolution) }\end{array}$ & $\begin{array}{l}\text { Fine/coarse fraction on whatman filter, } \\
\text { IC off-line }\end{array}$ & JRC Ispra \\
\hline $\begin{array}{l}\text { Total organic carbon and EC } \\
\text { (12 } \mathrm{h} \text { time resolution) }\end{array}$ & $\begin{array}{l}\text { Fine/coarse fraction on quartz filter } \\
+ \text { evolved gas analysis }\end{array}$ & JRC Ispra \\
\hline $\begin{array}{l}\text { Elemental composition/ } \\
\text { mineralogy ( } 12 \mathrm{~h} \text { time resolution) }\end{array}$ & $\begin{array}{l}\text { High-volume samples (PM10) on } \\
\text { whatman, analysis by WHICH TECHNIQUE }\end{array}$ & JRC Ispra + CNRS Paris \\
\hline \multicolumn{3}{|c|}{ Aerosol physical properties } \\
\hline Number concentration $>15 \mathrm{~nm}$ & Condensation nuclei Counter & JRC Ispra + CNR-ISAO \\
\hline $\begin{array}{l}\text { Number size distribution }(6-600 \mathrm{~nm}) \\
\text { ( } 5 \text { min time resolution) }\end{array}$ & Differential Mobility Analyzer (DMA) & JRC Ispra \\
\hline $\begin{array}{l}\text { Number size distribution ( } 300 \mathrm{~nm} \\
-10 \mu \mathrm{m})(1 \text { min time resolution) }\end{array}$ & Optical particle Counter (OPC) & JRC Ispra \\
\hline $\begin{array}{l}\text { Aerosol volatility }(6-600 \mathrm{~nm}) \\
\text { ( } 5 \text { min time resolution) }\end{array}$ & $\mathrm{DMA}$ + thermodenuder at $300^{\circ} \mathrm{C}$ & JRC Ispra \\
\hline $\begin{array}{l}\text { Aerosol hygroscopicity } \\
(10-200 \mathrm{~nm})\end{array}$ & Humidity Tandem DMA & JRC Ispra \\
\hline
\end{tabular}

The Mt Cimone, Italy, campaign: gaseous and aerosol composition

Y. Balkanski et al.

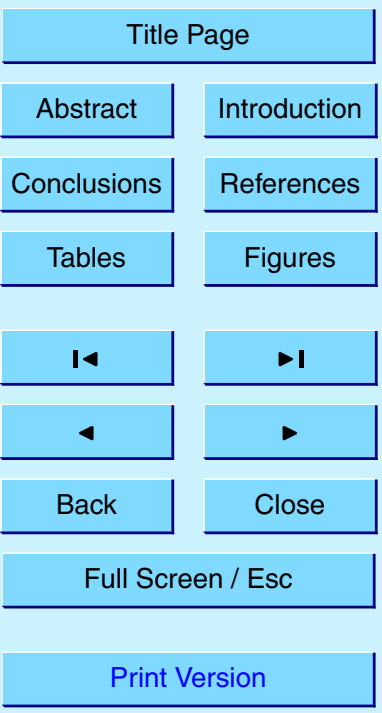

Interactive Discussion 


\section{ACPD}

3, 1753-1776, 2003

Table 1. Continued.

\begin{tabular}{|c|c|c|}
\hline Parameter & Instrument/method & Partner \\
\hline \multicolumn{3}{|c|}{ Aerosol optical properties } \\
\hline In-situ scatter coefficient & White light nephelometer & CNRS Paris \\
\hline In-situ light absorption coefficient & Aethalometer & JRC Ispra \\
\hline $\begin{array}{l}\text { Vertical profile of backscatter } \\
\text { ratio and depolarisation ratio (profile } \\
\text { includes measurement station altitude) }\end{array}$ & VELIS LIDAR & CNR-IFA Roma \\
\hline Aerosol optical depth & multi-band sunphotometers (CIMEL) & CNR-IFA Roma \\
\hline \multicolumn{3}{|c|}{ Meteorological parameters } \\
\hline $\begin{array}{l}\mathrm{T}, \mathrm{RH}, \text { Pressure, wind direction } \\
\text { and wind speed }\end{array}$ & & CNR-ISAO \\
\hline 10-days back trajectories analysis & FLEXTRA model & CNR-ISAO \\
\hline \multicolumn{3}{|c|}{ Forecasts and analysis } \\
\hline Meteorological & $\begin{array}{l}\text { BOLAM model, ISAO } \\
\text { METEOSAT IR, VIS, WV maps }\end{array}$ & \multirow{5}{*}{$\begin{array}{l}\text { Facilities at the Monte } \\
\text { Cimone station provided } \\
\text { by CNR-ISAO through } \\
\text { URL connection. }\end{array}$} \\
\hline 6 days 3D-back trajectories & HYSPLIT model, NOAA ARL & \\
\hline $\begin{array}{l}\text { Dust load, surface } \\
\text { concentration forecasts }\end{array}$ & DREAM model, Uni. Malta & \\
\hline Dust optical depth & NAAPS model, NRL Monterey & \\
\hline Radiosondes & Uni. Wyoming & \\
\hline
\end{tabular}

The Mt Cimone, Italy, campaign: gaseous and aerosol composition

Y. Balkanski et al.

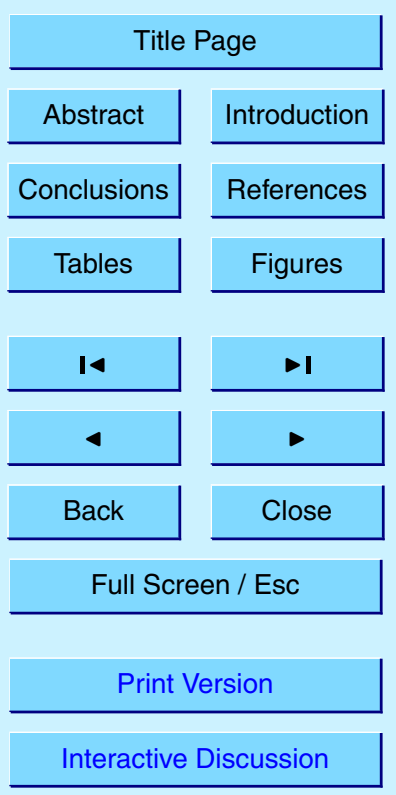

(C) EGU 2003 


\section{ACPD}

3, 1753-1776, 2003

Table 2. Ozone concentrations (ppbV) along air masses coming from the different wind sectors defined in the text. For columns 5 trough 9 , the concentrations in parenthesis for the run with homogeneous chemistry only and numbers without parenthesis are for the simulation including heterogeneous reactions with $\mathrm{O}_{3}, \mathrm{~N}_{2} \mathrm{O}_{5}, \mathrm{HNO}_{3}$ and $\mathrm{NO}_{3}$

\begin{tabular}{|c|c|c|c|c|c|c|c|c|c|}
\hline REGION & \# trajectories & $\begin{array}{l}\% \text { of all } \\
\text { trajectories }\end{array}$ & $\begin{array}{l}\begin{array}{l}\text { Measured } \\
\text { daily } \mathrm{O}_{3} \\
(\mathrm{ppbV}) \text { at } \mathrm{Mt}\end{array} \\
\text { Cimone }\end{array}$ & $\begin{array}{l}\text { Simulated } \\
\text { daily ozone } \\
\text { at Mt } \\
\text { Cimone }\end{array}$ & $\begin{array}{l}\text { Simulated } \\
\text { ozone averaged } \\
\text { for } 24 \mathrm{~h} \text { before } \\
\text { its arrival at } \mathrm{Mt} \\
\text { Cimone }\end{array}$ & \begin{tabular}{|l} 
Idem but \\
between 24 \\
and $48 \mathrm{~h}$ \\
before air \\
mass arrives \\
at Mt Cimone \\
\end{tabular} & \begin{tabular}{|l} 
Idem but \\
between 48 \\
and $72 \mathrm{~h}$ \\
before air \\
mass arrives \\
at Mt Cimone \\
\end{tabular} & \begin{tabular}{|l} 
Idem but \\
between 72 \\
and $96 \mathrm{~h}$ \\
before air \\
mass arrives \\
at the station \\
\end{tabular} & $\begin{array}{l}\text { Idem but } \\
\text { between } 96 \text { and } \\
120 \mathrm{~h} \text { before air } \\
\text { mass arrives at } \\
\text { the station }\end{array}$ \\
\hline NW-EUR & 34 & 13 & 60 & $65(68)$ & $62(65)$ & $51(54)$ & $49(52)$ & $49(51)$ & $50(52)$ \\
\hline W-EUR & 61 & 24 & 60 & $66(69)$ & $61(64)$ & $54(58)$ & $54(57)$ & $54(57)$ & $56(58)$ \\
\hline E-EUR & 39 & 15 & 60 & $68(71)$ & $67(70)$ & $62(66)$ & $60(65)$ & $62(66)$ & $61(65)$ \\
\hline MED & 88 & 34 & 56 & $61(66)$ & $59(64)$ & $56(61)$ & $57(60)$ & $57(61)$ & $58(62)$ \\
\hline AFR & 26 & 10 & 57 & $57(63)$ & $56(62)$ & $53(59)$ & $54(58)$ & $54(59)$ & $55(61)$ \\
\hline No Class & 11 & 4 & 64 & $71(73)$ & $67(70)$ & $59(62)$ & $54(58)$ & $51(53)$ & $65(57)$ \\
\hline All Cases & 259 & 100 & 59 & $64(68)$ & $61(65)$ & $56(60)$ & $56(59)$ & $56(59)$ & $57(60)$ \\
\hline
\end{tabular}

\section{The Mt Cimone, Italy, campaign: gaseous and aerosol composition}

Y. Balkanski et al.

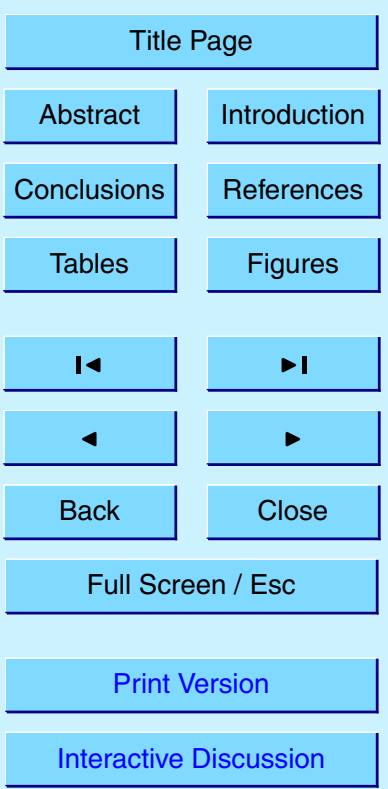




\section{ACPD}

3, 1753-1776, 2003

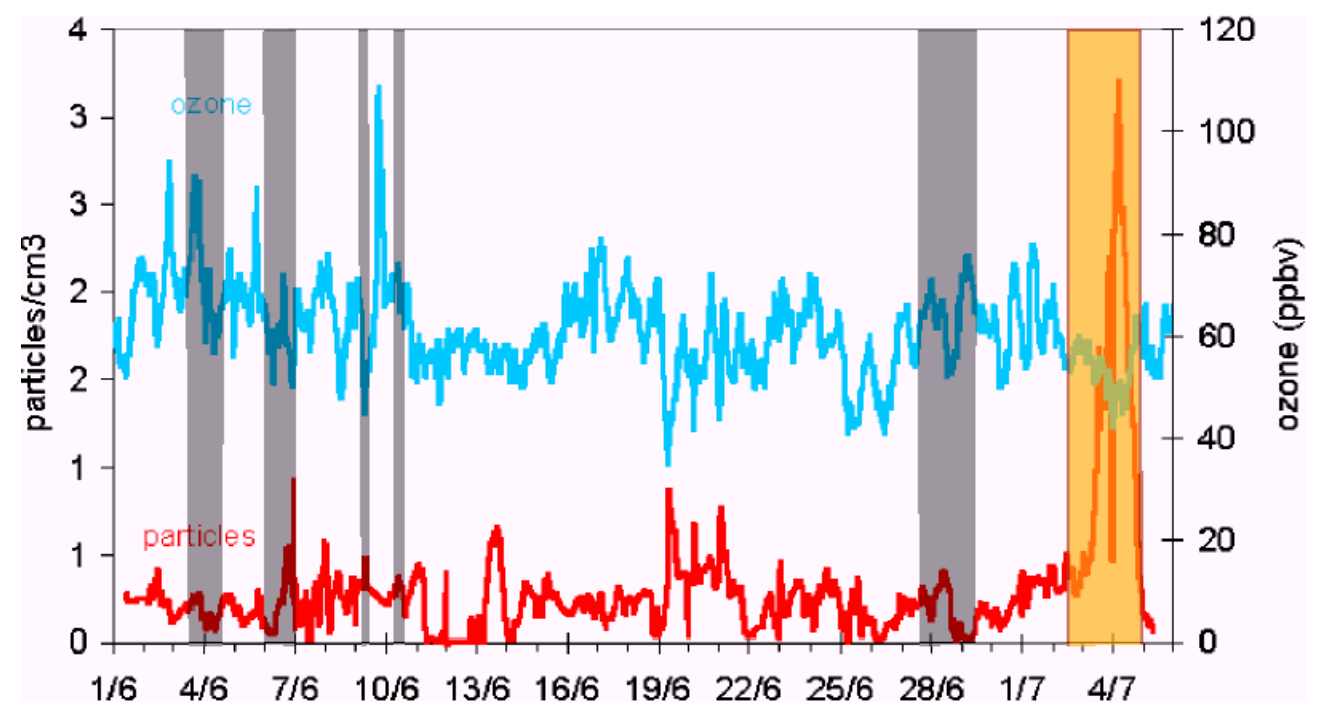

Fig. 1. Number concentration of aerosol particles with diameter $>1 \mu \mathrm{m}$ and surface ozone concentration for the period 1 June-5 July 2000 at Mt Cimone, Italy. The periods when dust layers were detected by the LIDAR are indicated by the shaded grey and yellow. The yellow shading indicates the only period when both significant dust amounts were measured by the optical particle counter at the Observatory and dust layers were detected by the LIDAR. Dust layers were identified through the measure of the depolarization ratio (indicative of the asymmetry of the particle).

\section{The Mt Cimone, Italy, campaign: gaseous and aerosol composition}

Y. Balkanski et al.

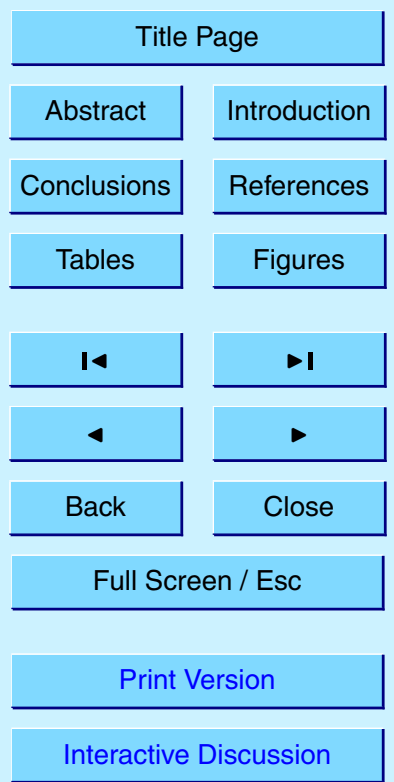




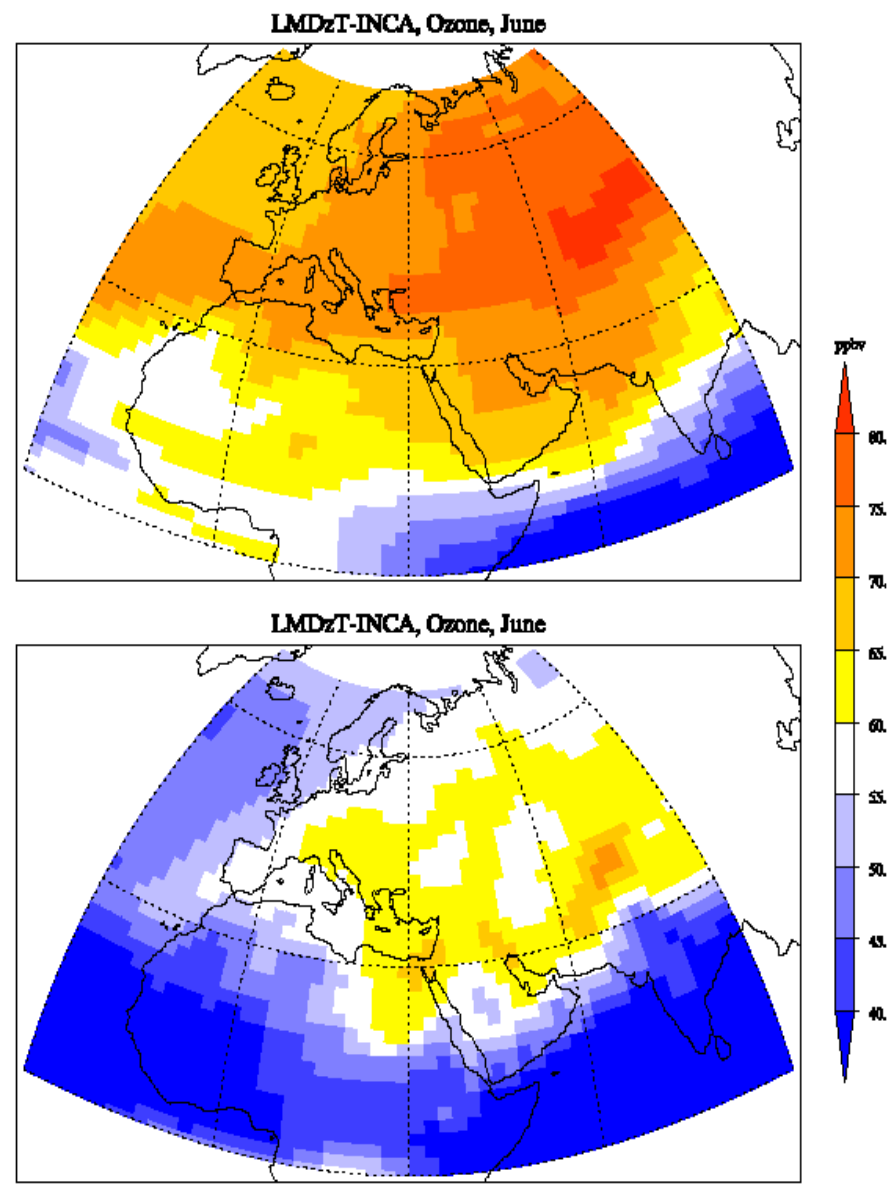

Fig. 2. June monthly mean ozone concentrations in ppbV at $400 \mathrm{mb}$ (Upper panel) and $780 \mathrm{mb}$ (lower panel) simulated by the LMDZ-INCA model.

\section{ACPD}

3, 1753-1776, 2003

The Mt Cimone, Italy, campaign: gaseous and aerosol composition

Y. Balkanski et al.

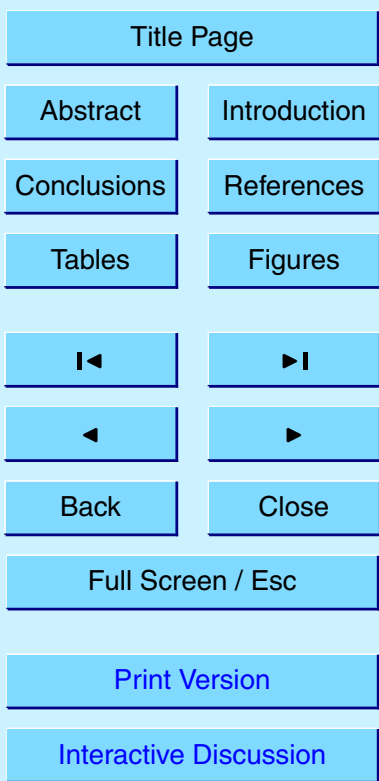

(C) EGU 2003 


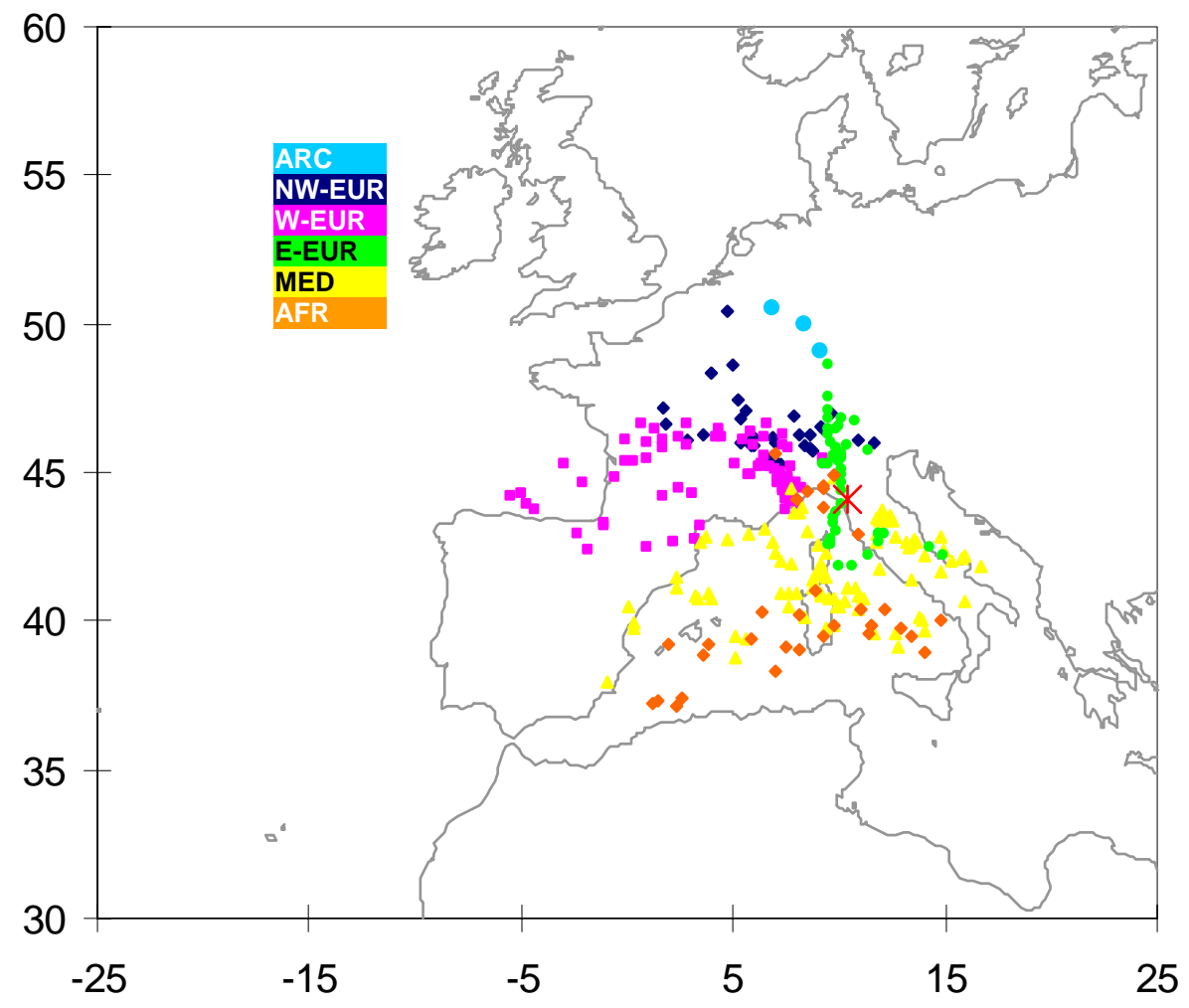

ACPD

3, 1753-1776, 2003

The Mt Cimone, Italy, campaign: gaseous and aerosol composition

Y. Balkanski et al.

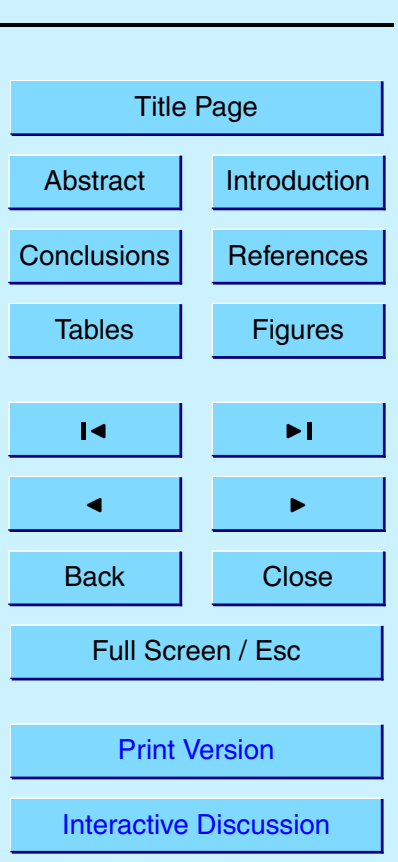

Fig. 3. Average position of the air mass associated to each trajectory. The coordinates of these points were obtained using a weight factor averaged along the trajectory. The weight factor is 1 at the time of arrival at MTC, and decays with $4 \% /$ backward per hour along the trajectory. This yields weight factors of $0.38,0.14$ and 0.05 , respectively for 1,2 and 3 days backward. By plotting these average positions on a map, one gets an idea of the "zone" contributing to the air mass properties before arriving at MTC.

Interactive Discussion 


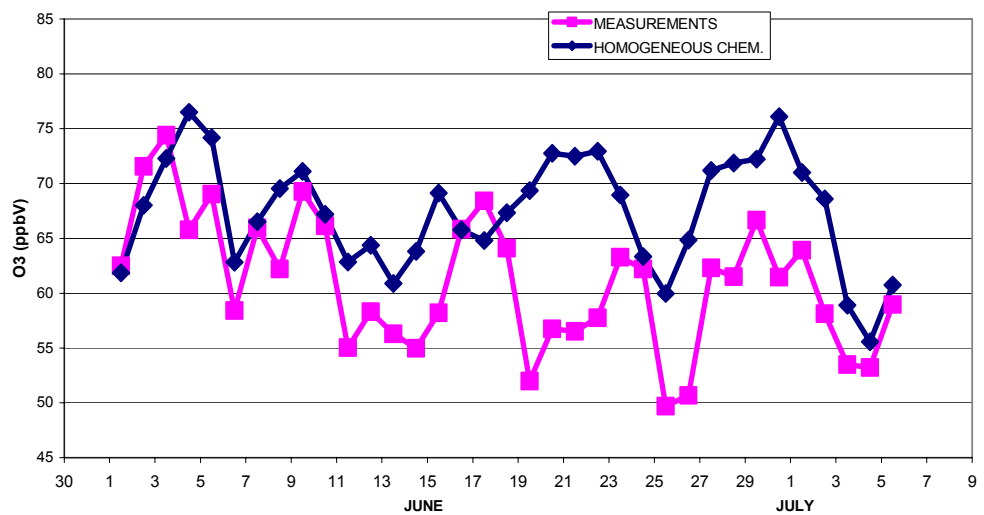

ACPD

3, 1753-1776, 2003

The Mt Cimone, Italy, campaign: gaseous and aerosol composition

Y. Balkanski et al.
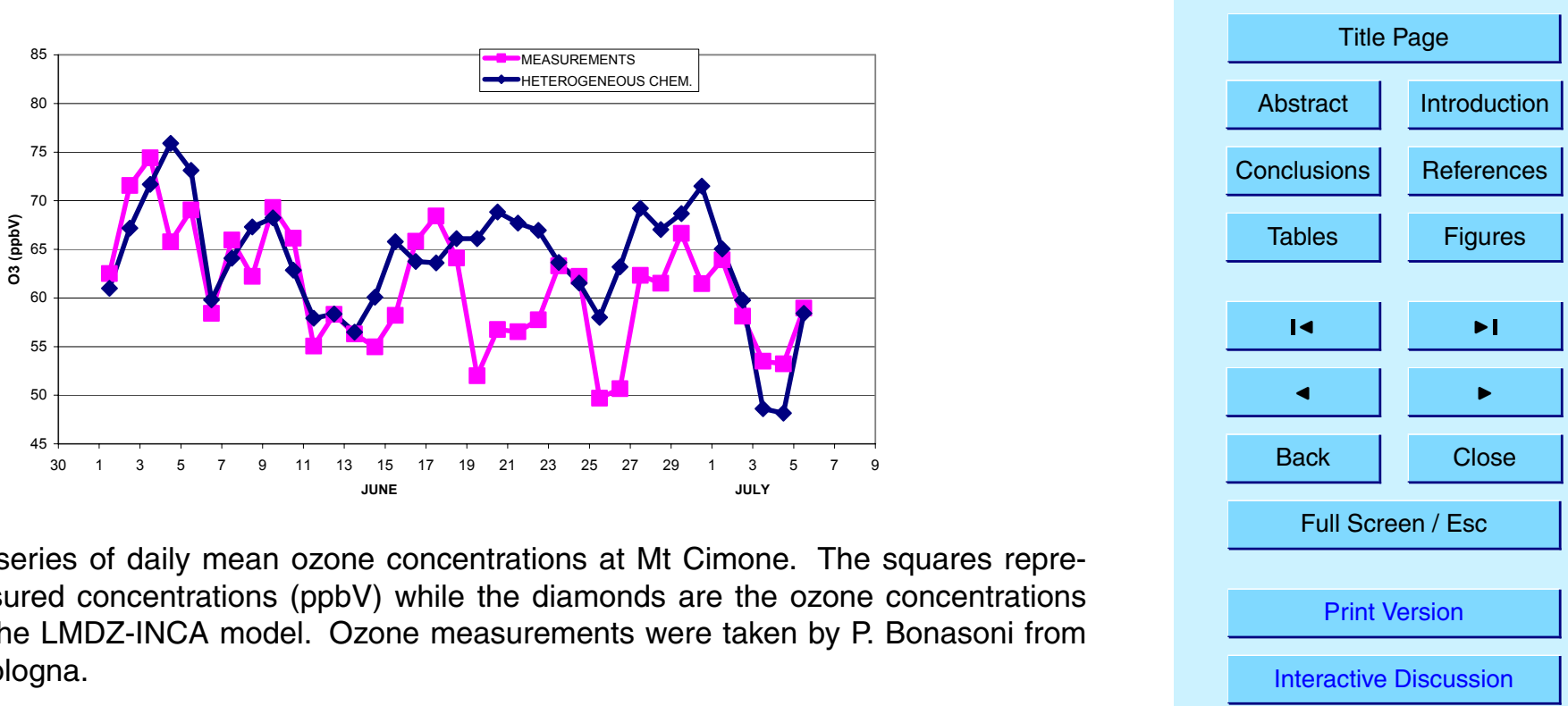

Fig. 4. Time series of daily mean ozone concentrations at Mt Cimone. The squares represent the measured concentrations (ppbV) while the diamonds are the ozone concentrations simulated by the LMDZ-INCA model. Ozone measurements were taken by P. Bonasoni from CNR-ISAC, Bologna.

Interactive Discussion 


\section{ACPD}

3, 1753-1776, 2003

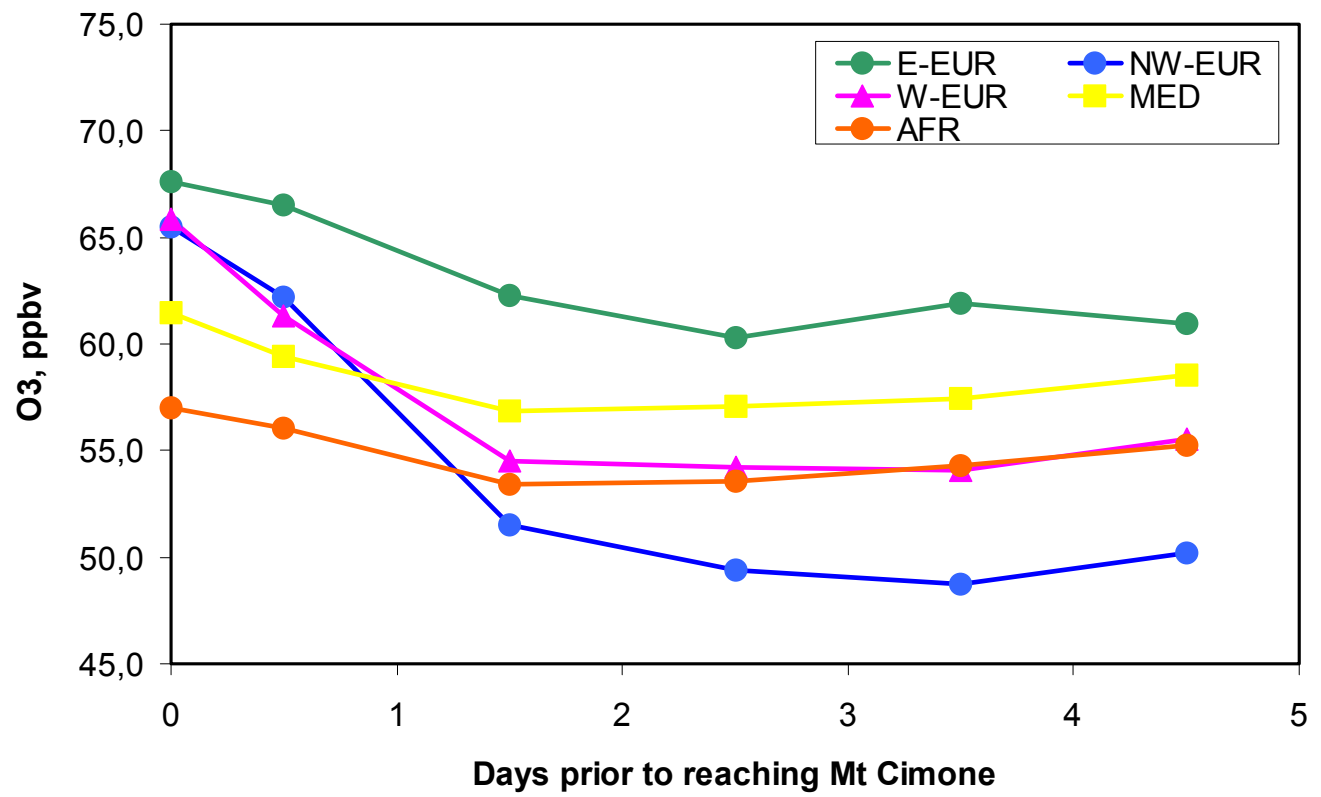

Fig. 5. Simulated mean ozone concentrations along the back trajectories arriving at Mt Cimone, respectively, $12,36,60,84$ and $108 \mathrm{~h}$ prior to the arrival time at the site.

The Mt Cimone, Italy, campaign: gaseous and aerosol composition

Y. Balkanski et al.

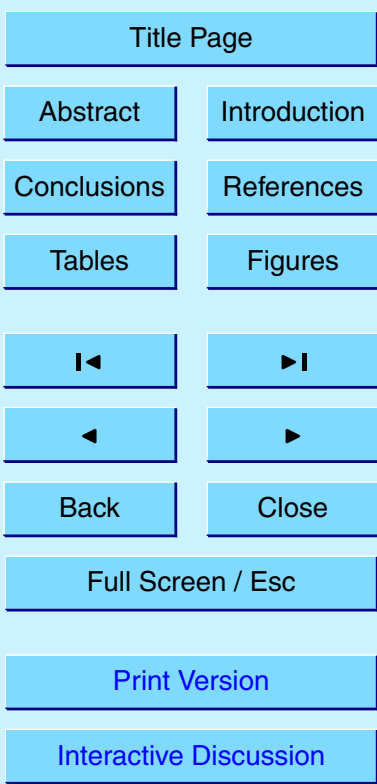

